\title{
The Dialogic Body and the Humanist Woman in the Self-Portraiture of Catherine des Roches
}

Le corps dialogique et la femme humaniste dans l'autoportrait de Catherine Des Roches

\section{Cathy Yandell}

\section{(2) OpenEdition}

\section{Journals}

Electronic version

URL: http://journals.openedition.org/aes/704

DOI: $10.4000 /$ aes.704

ISSN: 2258-093X

Publisher

Laboratoire LISAA

Electronic reference

Cathy Yandell, "The Dialogic Body and the Humanist Woman in the Self-Portraiture of Catherine des Roches », Arts et Savoirs [Online], 6 | 2016, Online since 12 July 2016, connection on 19 April 2019.

URL : http://journals.openedition.org/aes/704 ; DOI : 10.4000/aes.704

This text was automatically generated on 19 April 2019.

Centre de recherche LISAA (Littératures SAvoirs et Arts) 


\title{
The Dialogic Body and the Humanist Woman in the Self-Portraiture of Catherine des Roches
}

\author{
Le corps dialogique et la femme humaniste dans l'autoportrait de Catherine Des \\ Roches
}

Cathy Yandell

1 Uncovering the individual in the early modern period proves to be a rather daunting enterprise. As the story of Martin Guerre and many other sixteenth-century examples illustrate, individuals were defined less by what we might call character or particular traits than by the functions they fulfilled in society, as indicated by class, rank, familial role, and gender, as well as their "situatedness" in a particular geographical location the Périgord countryside for Montaigne, Lyon for Maurice Scève, and Anjou for du Bellay. Catherine des Roches poses particular challenges as we seek to unveil her self-portrait: beyond her predicable identification with her native Poitiers and the bourgeois status afforded to a lawyer's daughter, she forged a unique position for herself as a single woman of note, as half of an intellectual duo along with her mother, and as the first woman to negotiate the publication of her collected letters in the history of France. I propose to examine - and to rethink - a few commonplaces that have come to define Catherine des Roches in contemporary critical discourse, and in so doing to explore the nature of the dialogic body presented in her work.

\section{Corporeal (Af)filiation}

Symbiotically attached to one another, Catherine Fradonnet and her mother, Madeleine Eboissard, consciously chose to conflate their individual selves in the joint name under which they published and by which they came to be known: les Dames Des Roches. 
Capitalizing on their almost identical traits in both body and spirit, Madeleine dedicates the first poem of their first published works to her daughter:

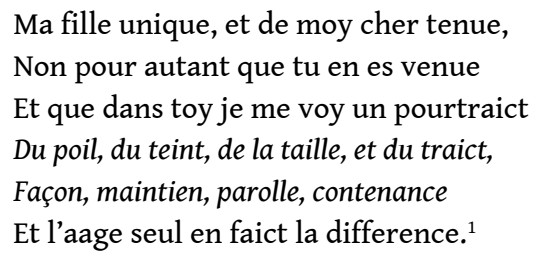

The asyndeton of line 5 "Façon /maintien/ parolle/ contenance" verbally underscores the continuity and the ostensible infinity of likeness between mother and daughter. The internal rhyme, "dans toy je me voy," adds to the seamlessness of first and second-person pronouns, and the caesura after "et l'aage seul" provides a rhythmic pause emphasizing that were it not for age, the two beings would be indistinguishable. For her part, Catherine uses the image of a shadow to evoke her exceptional attachment - both corporal and spiritual - to her mother: "Or connoissant que je tiens de vous, non seulement ceste mortelle vie, mais encore la vie de ma vie, je vous suy partout comme l'ombre le cors."

Madeleine and Catherine's contemporaries, too, evoked the indelible mother-daughter bond. Pierre Langlois imagines the two women metaphorically as a single, glorious bird:

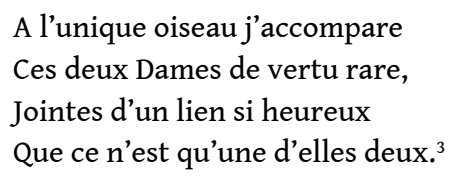

5 This image is striking in its opposition to the flighty bird often associated with women of the time, as illustrated in a famous engraving from Gilles Corozet's Hecatomgraphie of 1543 titled "La nature foeminine." 4

6 As Guillaume Colletet describes their relationship in his translation of Scévole de SainteMarthe, Éloges des hommes illustres (1644), "il y avoit entre elles une si grande union de coeurs, et de volontez, et une affection mutuelle si puissante et si forte, qu'elles disoient hautement qu'il n'estoit pas au pouvoir de la Mort mesme de les separer jamais l'une de l'autre" ${ }^{5}$.The wishes of Madeleine and Catherine that they never be separated did in fact come to pass, since they both died in October of 1584 , victims of the plague that ravaged Poitiers.

7 Contemporary critics have also insisted on a reciprocal devotion and the melding of wills between mother and daughter ${ }^{6}$. Colette Winn concludes, "Point de conflit entre la mère et la fille car désormais l'Autre se confond au Même." Similarly, Anne Larsen argues that "Catherine did not need to forge by herself a unique identity since she had in Madeleine a model of the scholarly woman whom she could imitate and then surpass."

In an explicit reversal of roles, Madeleine thanks her daughter in the "Epistre à ma fille" for caring for her through a number of trying situations (Madeleine was twice widowed while still relatively young, and lengthy legal procedures regarding property continued to plague her):

Tu as, enfant, apporté un cueur fort

Pour resister au violent effort

Qui m'accabloit, et m'offris dès enfance

Amour, conseil, support, obeissance.

$\cdots$

Que tesmoignant à la posterité 
Combien d'honneur tu auras merité,

Tu sois un jour par vertu immortelle,

Je t'ay tousjours souhaitée telle?.

Thus by her "vertu immortelle" ('vertu' in the dual sixteenth-century sense of both virtue and force or energy) Catherine has become the person her mother has wished her to be ("je t'ai tousjours souhaitée telle"). Without casting twenty-first century judgments on a sixteenth-century arrangement, we can nonetheless signal other passages in Madeleine's writing wherein Catherine is credited with the mother's happiness: “[tu] prends peine de me tirer hors des nuitz Cimerienes, où l'ignorance et la viellesse me tenoient ensevelie. Tu resembles au vert rameau qui, par sa naïve grace ... n'oublie jamais la vielle souche qui luy a donné un peu de matiere sans forme." 10

While at least one critic asserts that Catherine's mother served as "le garant de [sa] liberté"11, it seems to me that the nature of her freedom is more fraught than we have previously acknowledged. Even though Catherine's social status is not that of "wife," it remains that of "daughter" - and both roles in the sixteenth century involve exigencies that by convention define and confine them. While it would be anachronistic to suggest that Catherine sought complete physical and social autonomy, she nonetheless transcends familial bonds through her fictional literary creation, notably in the dialogue between the Neoplatonic lovers Sincero and Charite in her 1578 Euvres. An examination of her characters who speak in the first person reveals an important dialogic connection between the bodiless, sexless daughter of the letters and the physically engaged lover of her fictional work.

\section{Embodied Pleasure}

The repeated references to the symbiotic sameness of mother and daughter neglect one quality that does indeed separate and distinguish Catherine from her mother: her celebrated "chasteté", the quintessential quality for ensuring the good name of a single woman. As the character Raffaella notes in Piccolomini's dialogue of 1539, "l'onore non è riposto in altro, se non nella stimazione appresso agli uomini" (honor is held nowhere other than in repute among men) ${ }^{12}$. Both Catherine and her mother understand this dictum and exploit it repeatedly. In the first sentence of her dedication to the Secondes Euvres, Madeleine mentions her daughter's "honnéte pudeur". While it would not be appropriate for a young woman in polite society to boast about her own chastity, Catherine skillfully ventriloquizes the question in her Dialogue de Charite et de Sincero. In this dialogue, Charite, the fictional character who most closely resembles the author, refers to herself as "une chaste maistresse" (Euvres 274). The equivalence of Catherine and her fictional character is corroborated by the name Charite itself: the letters of the two lovers' names, Charite and Sincero, form an almost perfect anagram of Catherine Rocis $^{13}$. Sincero also addresses his beloved as "chaste et belle" (260) and "chaste, sçavante et belle" (p. 266). Not coincidentally, the operative terms other writers use most frequently to describe Catherine are "belle," "savante", and especially "chaste". Scévole de Sainte Marthe dedicates a poem to her titled "Sonnet encor à elle, par sa grand' chasteté"14.

11 If Charite is meant to represent Catherine in the "Dialogue de Charite et de Sincero," how are we to interpret what might be called the passionate version of chastity advanced in this work? The dialogue opens with a discussion of the love at first sight, or 
innamoramento, of Sincero, who has been carried to heaven by Charite's divine beauties ( $\mathrm{p}$. 252). Sincero's exaggerated Neoplatonic claims are met with a gently mocking rebuttal by Charite:

SINCERO: Madame, je persevere tousjours en mes premiers propos, et ma requeste premiere, demandant à voz graces, puisqu'il leur plaist bien quelquefois de me conduire au Ciel, qu'elles ne desdaignent non plus de me guider en terre.

CHARITE. Puisque vous ne pouvez encore vous guider en terre sans ayde d'autruy, comment vous mettez-vous à vouloir rechercher le Ciel ?

SINCERO. Vous en estes cause, Madame, car j'y suis conduit par vous, et vous par moy.

CHARITE. Si n'ay-je point souvenance d'y avoir jamais esté ; mais possible m'en ferezvous revenir la mémoire me disant ce que j'aperceu de plus esmerveillable en ce voyage. (p. 253)

12 Charite's playful humor deflects Sincero's encomium here, but without squelching his efforts. In a series of twelve sonnets and two chansons, Sincero declares his love, replete with Petrarchan images of the suffering poet's captivity:

... Je veux mourir cent fois en ma douce prison,

Laissant ma liberté, ma vie, et ma raison

Dans voz yeux, dans vos mains, et vostre blonde tresse. (p. 262)

13 While Catherine's rebuke of Neoplatonic and Petrarchan commonplaces is manifest, the story does not end there. In another series of sonnets, Charite lays out her requirements: her lover must be kind, temperate, just, prudent and strong. Above all, he must remain faithful to her: "Je veux que Sincero m'ayme juqu'à la mort / Me retenant pour tout unique maistresse" (271). A subsequent passage reprises this sentiment:

Sincero mon desir, je n'eu jamais envie

D'aymer autre que vous : mais aussi ne pensez

D'aymer autre que moy, et ne vous avancez

De chercher autre nœud que celuy qui nous lie. (p. 272)

14 While Charite speaks of "les honnestes plaisirs ... d'une chaste maistresse," (p. 275), she also evokes "cette flamme nouvelle" (p. 273) and addresses Sincero as "mon doux feu." She eventually admits her own love for him, "Recevant un amour, un amour je veux rendre / A vous, mon Sincero, et confesse mon heur ..." (p. 275). In Charite's final sonnet, the speaker is at last convinced of her lover's sincerity and pens a euphoric response, followed by a chanson in which the speaker's sentiments take on physiological manifestations: "Incessamment je souspire,/Et ne fay que lamenter ..."(p. 281-82). In a final display of ardor, Sincero responds to Charite's melancholy, inviting her to look upon herself, but then counters his invitation in a mannerist retraction:

Ha! n'y regardez plus, Madame, car j'ay poeur

Que vous reconnoissant si parfaicte en mon cueur,

Vous-mesme ne brulez dans voz propres flammes! (p. 283)

The poetry of both Charite and Sincero is thus replete with the conflicting emotions of lovesickness : melancholy, lack of sleep, and the verbs "soupirer," "lamenter" and "bruler" all record physical effects on the lovers, betraying a corporal passion that seems as much a part of this idealized love as the chastity it seeks so assiduously to represent. 


\section{The Epistolary Body and the Economy of Exchange}

16 While Madeleine and Catherine des Roches were heralded as the first women to publish their collected correspondence in France, they were in all likelihood the first writers of any gender at all to publish their collected letters. Estienne Pasquier claims to have been the first to publish a collection of private letters in France, but the records of publisher Abel L'Angelier show otherwise: the privilèges for the Dames des Roches were signed on March 1, 1586, and those of Pasquier on June 7 of the same year. Pasquier, a lawyer at the Parlement of Paris, was a participant in the Des Roches' literary salon and held Catherine in the highest regard, "entre les belles, honnestes et vertueuses dames de la France"15. Perhaps the Des Roches were willing to cede to Pasquier this claim to fame in exchange for the public compliments of this well-known figure in the Parisian literary establishment ${ }^{16}$.

17 This likely quid pro quo suggests the kind of relationship between letter-writers that abounds in the Missives. Arlette Jouanna has analyzed the correspondence of nobles in this period, noting the recurrence of the words "dette", "obligation", "service", and "devoir"17. Catherine, too, often frames the exchange of letters in terms of gift and return gift. To a correspondent who has offered her a poem, she responds:

Si je voulois tourner vostre don en eschange,

Respondant aux beaux vers escris de vostre main,

Ce serroit vous priver d'une haute louange :

Car le don vient du ciel, et le change est humain. (Missives 325)

Marcel Mauss, in his canonical Essai sur le don, emphasizes the personal and social dimensions of exchange in every human society ${ }^{18}$. In breaking slightly with this tradition, Jacques Derrida notes that each time there is restitution or a countergift, the gift is annulled - there is payment or discharge of a debt ${ }^{19}$. Catherine des Roches's letters illustrate that this latter principle did not necessarily obtain in sixteenth-century correspondence: in a tautological twist, Catherine insists on the continuity of epistolary indebtedness: "Mais je me trompe vraiment, plus je paye ma debte, plus je suis obligee: puis que vostre excellence est telle que vous honorant je me fais honneur" (Missives, p. 205-206).

This letter aptly illustrates the nature of Catherine des Roches's correspondence as "lettres de compliment," steeped in the etiquette of salon and court culture, wherein epistolary writers strive principally to please, or not to displease ${ }^{20}$. Luc Vaillancourt points out that the strategy of drawing attention to the other becomes a subtle way to honor oneself in a culture in which courtesy is a supreme virtue ${ }^{21}$. But while the repayment of praise at first glance appears to be a return compliment, upon closer examination, we see that it constitutes a deflection of the sentiments expressed in the admirer's letter: "Vous dites que vous ne me pouvez dignement louër. Vrayment je le croy, mais c'est pource que je suis indigne de loüange : et puis vostre excellence ne loüe que ce qui est excellent comme elle"22 (p. 166). Thus while still aiming to please, Catherine is simultaneously firmly rejecting suitors. Seen in this light, Catherine's goals appear to be at cross-purposes, at once inviting and declining, embracing and dismissing.

In a related example, having received a mirror from an unidentified admirer, Catherine adroitly turns around the meaning of the gift. Not only did the mirror appear as a metonym for coquettishness in this period, as evidenced by François Clouet's iconic 
"Dame à sa toilette" (among others), but it also served to exploit the friendly rival motif, as in Ronsard's "Je parangonne à voz yeulx ce crystal" ${ }^{23}$, in which the poet envies the felicitous mirror that will be able to gaze at length at the lady. Moreover, in many visual depictions, the mirror appears as Venus's accessory, as in Titian's "Venus with a Mirror" of 1555. Given this context, the gift to Catherine was no doubt intended as compliment to her beauty, yet she rejects that reading and turns it into a lesson in Greek philosophy: "Ayant receu de vostre liberalité un veritable et precieux miroir, j'ay pensay lire dedans sa claire face la sentence d'Apollon, Cognois-toy mesmes." (p. 207-208)

In contrast to Catherine's deliberate cluelessness about the possible meaning of this mirror in the Missives, consider the sonnet from Charite to Sincero in which Charite sees her own reflection in Sincero's thoughts, eyes, and heart:

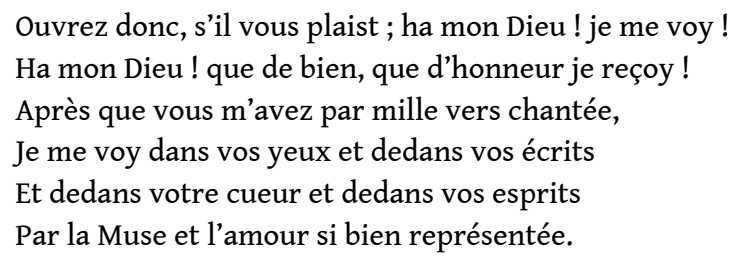

In this poem, in opposition to the previous example, the amorous association with the mirror is not rejected, but rather embraced: the lover's eyes reflect the beloved, thus affirming Sincero's assurances to Charite. Once again, what cannot be espoused by the writer Catherine is appropriated and embellished by her character Charite.

Catherine des Roches may not have lived a passionate or erotically inspired life, but she created one for her characters. In Charite she constructs an independent spirit who nonetheless grew to trust her lover, and in Sincero, a lover for whom Ficinian reciprocity and mutual devotion are paramount ${ }^{24}$. Catherine, foreseeing potential criticisms that she should not write love poetry, responds proactively that she wrote only what she conjured up, not what she had personally seen, for she knew Sincero only through her imagination (p. 182). She describes him as the "parfait amoureux", modestly noting that just as God created Eve to be like Adam, so she has created Charite to be as much like Sincero as possible, “à son patron le plus qu'il $\mathrm{m}$ a esté possible... luy donna[nt] une femme semblable à luy (p. 182-183). Catherine states explicitly elsewhere that she is not envious of Charite's happiness (Missives 183), but it is impossible to confirm the veracity or the fallaciousness of that claim. Perhaps the lady doth protest too much, but in any case, the text remains as historical document, and the gesturing toward reciprocity so evident in the Missives finds its full expression in the amorous relationship embodied by Charite and Sincero.

The literary portrayals of Catherine, sketched by both herself and others, did indeed project a chaste, intellectual persona unfettered by sexual attachment. At the same time, as we have seen, that disembodied stance is often complicated and moderated in the text by a lexical field in which physicality, love, and even passion appear ${ }^{25}$. The verdict remains open as to whether Catherine's approach to the relationship between the intellect and the physical body is ultimately an example of dialectic, in which a synthesis is achieved between the antithetical poles of the chaste and bodiless erudite, on the one hand, and the sensuous, playful woman-in-her-own body, on the other. Most contemporary critics have argued that Catherine des Roches, through a combination of her bold writing, her lily-white personal reputation, and her mother's watchful protection, succeeded in negotiating for herself a literary renown that would have been 
impossible under other circumstances. Given the social strictures of the epoch, had Catherine des Roches married, she may indeed have been forced to abandon her profession. But her self-portraiture in the largest sense suggests another fundamental conclusion that the epithet of "tresvertueuse et docte fille" obscures: in Charite, who both reflects and extends the first-person narrator of the poems and letters, she inscribes a dialogic body that is at once learned and sensuous, resistant and engaged. In so doing, Catherine des Roches paves the way for a new kind of female writer, if only in a fictional world - a sexualized and embodied humanist woman.

\section{NOTES}

1. Catherine des Roches and Madeleine des Roches, CEuvres (1579), Anne R. Larsen ed., Genève, Droz, 1993, p. 82, my emphasis.

2. Catherine des Roches and Madeleine des Roches, Secondes CEuvres, Anne R. Larsen ed., Geneva, Droz, 1998, p. 119.

3. Pierre Langlois, Discours des Hieroglyphes égyptiens, Paris, Abel L'Angelier, 1583, fol. 58v-59r.

4. Gilles Corrozet, Hecatomgraphie (Paris: Denis Jadot, 1543) n.p. The emblem can be viewed in Gallica, http://gallica.bnf.fr/ark:/12148/bpt6k70938k/f2.image.r=Corrozet,\%20Gilles, vue 169. The motto is also revealing: "Je suys de la complexion / Des petits oyseaux que je garde./Je suys d'aussi maulvaise garde / Qu'ilz sont, en leur condition."

5. Scévole de Sainte-Marthe, Éloges des hommes illustres qui depuis un siècle ont fleuri en France dans la profession des lettres, composés en latin par Scévole de Ste-Marthe, et mis en français par G. Colletet, Paris, Antoine de Sommaville, 1644, p. 340.

6. Madeleine Lazard, “Les Dames des Roches: une dévotion réciproque et passionnée”, ed. Roger Duchêne et Pierre Ronzeaud, "Autour de Mme de Sévigné. Deux colloques pour un tricentenaire. Rapports mère-fille au XVII ${ }^{\mathrm{e}}$ siècle et de nos jours; Les Voyages en France au XVII ${ }^{\mathrm{e}}$ siècle", Papers on French Seventeenth-Century Literature, 1997, p. 9-18.

7. "Miroir d'elle-même, l'image filiale fait naître en la mère non le désir de maîtrise, d'autorité, de possession, mais plutôt la voluptueuse sensation que procure la transgression des limites, l'abolition des divisions, la fusion/ confusion à l'autre", Colette H. Winn, "Mère/ fille/ femme/ muse: maternité et créativité dans les œuvres des Dames des Roches", Travaux de Littérature, 1991, 55.

8. Anne R. Larsen, “Legitimizing the Daughter's Writing: Catherine des Roches' Proverbial Good Wife", The Sixteenth Century Journal 21.4 (1990): p. 559-574, citation p. 573-574.

9. Catherine des Roches and Madeleine des Roches, op. cit., p. 83-84.

10. Catherine des Roches and Madeleine des Roches, Les Missives, Anne R. Larsen ed., Geneva, Droz, 1999, p. 5.

11. Lazard, op. cit., p. 17.

12. La Raffaella, ovvero Della bella Creanza delle Donne, Milan, Daelli, 1862, p. 50 . See also Jean-Claude Carron, "Les Noms de l'honneur féminin à la Renaissance. Le Nom tu et le non dit", Poétique 67, 1986, p. 269-280. On the general question of women's honor in the period, see La catégorie de l'Honneste dans la culture $d u \mathrm{XVI}^{e}$ siècle, Gabriel-André Pérouse ed., Saint-Étienne, Université de Saint-Étienne, 1985. 
13. See Janet Levarie Smarr, Joining the Conversation: Dialogues by Renaissance Women, Ann Arbor, University of Michigan Press, 2005, p. 176.

14. BnF, Ancien Fonds français 862, 33v, cited by Larsen, Les Missives, op. cit., p. 310.

15. Estienne Pasquier, Lettres familières, Dorothy Thickett ed., Geneva, Paris, Droz, 1974, p. 187.

16. As Luc Vaillancourt puts it, "quitte à racheter ensuite la sympathie des dames de Poitiers par quelques compliments", La lettre familière au seizième siècle. Rhétorique humaniste de l'épistolaire, Paris, Champion, 2003, p. 319, n. 9.

17. Arlette Joanna, Le devoir de révolte. La noblesse française et la gestation de l'État moderne (1559-1661) , Paris, Fayard, 1989, p. 83.

18. Marcel Mauss, Essai sur le don. Forme et raison de l'échange dans les sociétés archaïques, Paris, PUF, 2007.

19. “Pour qu'il y ait don, il faut qu'il n'y ait pas de réciprocité, de retour, d'échange, de contredon ni de dette", Jacques Derrida, Donner le temps, Paris: Galilée, 1991, p. 24 ; Given Time: I. Counterfeit Money, trans. Peggy Kamuf, Chicago, University of Chicago Press, 1992, p. 12.

20. "Cette passion de plaire se situe au carrefour de préoccupations morales, esthétiques et sociologiques et forme la trame des relations mondaines de l'Ancien Régime", Marie-Claire Grassi, Lire l'épistolaire, Paris, Dunod, 1998, p. 36.

21. Vaillancourt, op. cit., p. 324.

22. Other examples of this techniques abound: "Tout ainsi que ma presence ne vous sçauroit bienheurer, ainsi l'absence de moy ne vous peut rendre mal-heureux, pource que vous portez tousjours avec vous les moyens que vous dites estre seuls forgeurs de vostre felicité", Missives, p. 169 ; "Mais je ne sçaurois penser quelle occasion vous avez prise pour vous loüer de moy, sinon celle que vous m'avez donné pour me loüer de vous; pource que j'ay receu les faveurs dont il vous a pleu m'estre si liberal, qu'il sembloit que me faisant grace, vous-mesme la receviez. Mais n'estoit-ce point assez (Monsieur) de m'avoir obligée par tant de bienfaits, sans que je le soie encore par l'infinité de vos courtoisies; si je dis jamais parole qui vous plust, vous me l'avez renduë, comme la terre fertile qui pour un grain rend un espy", p. 175; "Monsieur, il me semble voir le beau et bon desiré par les Philosophes, quand je pense aux deux personnages engravez au frond et au sein de vos lettres : il me semble encore que parlant d'eux et de moy, vous avez representé une image de vous mesmes; car toutes ces excellences dont vous parlez se viennent rendre en vostre ame...", p. 198.

23. Pierre de Ronsard, Cuuvres complètes, Jean Céard, Daniel Ménager et Michel Simonin ed., Paris, Gallimard, 1993-1994, vol. 1, p. 62.

24. This same reciprocity is resumed in "Chanson de Sincero" and "Chanson de Charite" in Les Secondes Euvres, op. cit., p. 262-265.

25. For an analysis of parallel questions in the "Dialogue d'Iris et Pasithée" see Cathy Yandell, "Les ames sans cors et les cors sans ames. La pédagogie dialectique de Catherine des Roches", Lectrices d'Ancien Régime, Isabelle Brouard-Arends ed., Rouen, Presses Universitaires de Rennes, 2003, p. 557-566. Several studies have examined the corporal nature of Catherine des Roches, "La puce de Madame Des Roches", Ann Rosalind Jones, "Contentious Readings: Urban Humanism and Gender Difference" in La Puce de Madame Des-Roches (1582)", Renaissance Quarterly 48.1, 1995, p.109-128; Cathy Yandell, "Of Lice and Women. La Puce de Madame des Roches", Journal of Medieval and Renaissance Studies $\mathrm{n}^{\circ}$ 20, 1990, p. 123-135; Kendall B. Tarte, Writing Places. Sixteenth-Century City Culture and the Des Roches Salon, Newark, Université of Delaware Press, 2007, p. 26-36; and Leah Chang, Into Print. The Production of Female Authorship in Early Modern France, Newark, Université of Delaware Press, 2009, p. 76-84. 


\section{ABSTRACTS}

In her "Dialogue de Sincero et de Charite", Catherine des Roches creates an equally intelligent and lettered character in Charite, who embodies both erudition and erotic desire. A reading of the "corporal [af]filiation" between mother and daughter indeed reveals the symbiotic attachment of mother and daughter in both literary and social spheres. Yet a more refined version of Catherine's self-fashioning can be glimpsed in her Missives. Through a juxtaposition of these two characters, to varying degrees historical and fictional, the image of a dialogical body emerges in the CEuvres. What might be described as a hybrid self-portrait thus exposes a distinct vision that the epithet of "tresvertueuse et docte fille" obscures: in Charite, who both reflects and extends the first-person narrator of the poems and letters, Catherine des Roches inscribes a dialogic body that is at once learned and sensuous, resistant and engaged-in short, a new model for the humanist woman.

Dans son «Dialogue de Sincero et de Charite », Catherine des Roches crée un personnage aussi intelligent que lettré, qui incarne à la fois l'érudition et le désir érotique. Une lecture de l'«affiliation corporelle » entre fille et mère révèle bien une symbiose dans les sphères sociale et littéraire, mais on peut entrevoir une version plus fine du façonnage de sa propre identité dans les Missives. À travers la juxtaposition de ces deux personnages, historiques et fictifs à des degrés divers, l'image d'un corps dialogique émerge dans les Euvres. Ce qui pourrait être décrit comme un autoportrait hybride expose ainsi une vision distincte que brouille l'épithète de «tresvertueuse et docte fille » : en Charite, qui à la fois reflète et développe la première personne du narrateur des poèmes et des lettres, Catherine des Roches inscrit un corps dialogique qui est à la fois savant et sensuel, résistant et engagé -en bref, un nouveau modèle pour la femme humaniste.

\section{INDEX}

Mots-clés: Des Roches (Catherine), Roches (Madeleine des), don, femmes savantes, corps dialogique, lien mère-fille, représentation littéraire

Keywords: Des Roches (Catherine), Roches (Madeleine des), dialogic body, gift, learned women, literary portrayals, mother-daughter bond

\section{AUTHOR}

\section{CATHY YANDELL}

